\title{
A DonZela-Guerreira: Um EsTUdo DE GÊNERo*
}

\author{
CREUD PEREIRA SANTOS MARTINELLI
}

Estudos de gênero, por mais atuais que pareçam, não privilegiam uma reflexão exclusiva da modernidade. Os antigos compêndios egípcios de astrologia já percorriam um caminho que levantava a questão e, com muita clareza, sinalizavam para uma concepção de diferença sem exclusividade. Sol e Marte eram considerados planetas cujas energias respondiam pelos caracteres masculinos - o chefe da família, o guerreiro -, em oposição à Lua e Vênus cujas influências eram determinantes para a mulher, regulando sua carga hormonal não apenas para funções de procriação e nutrição, mas também para as de amante, objeto de prazer erótico - a mãe, a prostituta.

A constatação da diferença, portanto, não delimitava rígidas fronteiras nem tampouco ignorava a complexidade de matizes de que se tem revestido o comportamento humano. Assim, ainda que os horoscopistas de aluguel de nossa imprensa tenham banalizado os conhecimentos dessa sabedoria milenar, com previsões e sínteses de traços de personalidade produzidas em atacado para atender leitores superficialmente sintonizados com a moda ocultista, os estudiosos da Antigüidade, antecipando uma vertente individualista, alertavam que, mesmo o mais viril dos homens, se fortemente marcado por energias de Vênus, expressar-se-ia mais suave e artisticamente frente a outro que, à guisa de exemplo, ostentasse um Marte natal angulado pelos raios carregados da seriedade de um Saturno ou da espiritualidade de Netuno. A influência lunar na carta natal de um homem poderia oferecer uma coloração mais feminina a seu caráter e 
levá-lo a priorizar a vida doméstica em detrimento da aventura oferecida pelo mundo teoricamente masculino, exterior às paredes do lar, sem lhe comprometer, entretanto, a especificidade sexual.

Há que se ponderar, portanto, no bojo dessa leitura de mundo fundamentada nas estrelas e planetas, independentemente de quaisquer outras objeções e elas são muitas -, uma concepção de homem e de mundo multifacetada, na medida em que incorpora diferenças individuais e que, estranhamente, extrapola os limites da rigidez característica dos papéis sociais.

Com relação ao feminino, a questão adquiria uma complexidade até maior, pois sua regente natural, a Lua, colaborava para a construção de crenças fundamentadas na possibilidade de que pudesse ser responsável por idiossincrasias as mais inesperadas. Primeiramente, porque a Lua nem é um planeta, ocupando posição de exceção entre eles; e, em segundo lugar, suas influências, no comportamento humano e na natureza, desfrutavam uma aura de mistério, instabilidade, imprevisibilidade, passível de ser constatada não apenas a olho nu nos variados formatos dos ciclos de Cheia, Crescente, Minguante e Nova, mas também pelos efeitos que se lhe atribuíam com relação à colheita, às marés, aos humores de animais etc. Como os homens, qualquer mulher cuja Lua natal estabelecesse angulações com outro planeta também estaria sujeita a diferenças muito particulares em seus traços femininos: os raios de Vênus poderiam beneficiá-la com uma sensibilidade artística acentuada, os de Saturno transforma-la-iam numa bruxa, os de Mercúrio confeririam agudeza intelectual. Em especial, as guerreiras, dominadoras e aventureiras teriam sido banhadas, por ocasião do nascimento, com os raios poderosos de Marte, capazes de dotá-las de fortes características masculinas. De qualquer forma, em se tratando do feminino, acrescentavam-lhe ainda um outro ingrediente: o mistério inerente à própria Lua..

São sobre essas últimas que se debruça o trabalho da professora Walnice Nogueira Galvão, A donzela-guerreira: um estudo de gênero. É esta mulher, corajosa o suficiente para expressar publicamente energias marcianas mais próprias do masculino - a quem os astrólogos não titubeariam em utilizar como um exemplo de uma Lua angulada por Marte, para o pior ou melhor -, que polariza sua atenção. A obra persegue c comprova a incidência desse tipo na literatura, em diferentes mitologias, culturas, civilizações e momentos históricos. A autora localiza a donzela-guerreira sob as vestes da jovem grega Atalanta, como Dô-Nhã, Mula-Marmela ou Doralva em Guimarães Rosa, na pele das belicosas amazonas em Macunaíma, na saga da orgulhosa rainha africana Jinga. Nessa galeria figuram personagens históricas como Clara Camarão, a cangaceira Maria Bonita, Anita Garibaldi e Maria Curupaiti, lendárias pela participação na Guerra do Paraguai, e a sonhadora e infeliz Jovita Alves Feitosa. Paralelamente, não foram esquecidas Luzia-Homem, Dona Guidinha do Poço, e tantas outras personagens como as da prosa de Alencar e mesmo o Orlando de Virgínia Woolf.

Segundo a autora, para melhor compreendê-la, "é preciso compará-la com as demais. Entre tantos destinos de mulher, ela se destaca, de saída, por ser outra: ela não é mãe, nem esposa, nem prostituta, nem feiticeira, etc. Seu nicho muito especial deve ser procurado ali onde não radica nenhuma dessas". Recusando-se a atender às expectativas próprias de seu sexo, a donzela-guerreira - 
que necessariamente não precisa ser donzela, pois pode pugnar ao lado do cônjuge - caracteriza-se pelo ardente desejo de invadir áreas tradicionalmente proibidas à experiência feminina.

Ao lado da mulher fatal, da mulher anjo, da outra, a donzela-guerreira de Walnice Nogueira Galvão não pretende solucionar o mistério do eterno feminino, como revela o título do último capítulo, "Arremate: o enigma". A pesquisa, seleção textual e organização da obra iluminam, portanto, mais um contorno do enigma, contribuindo de forma inovadora para a compreensão da trajetória das mulheres, ratificando, isto sim, como bem compreende a autora, a inferência da relatividade na definição mútua dos gêneros.

Quando consultavam o céu para sondar o destino, os antigos astrólogos já sabiam que todas as estrelas são diferentes, embora iguais quando contempladas no firmamento. Vale lembrar aqui o célebre escrito do egípcio Hermes Trimegisto, registrando a resposta que a deusa Ísis dá ao filho Hórus quando questionada sobre as almas nascerem macho ou fêmea: "As almas, meu fillho Hórus, são iguais por natureza: não há entre elas nem macho nem fêmea; esta distinção só existe nos corpos encarnados". 